\section{PERKEMBANGAN SENI KRIYA DI TENGAH PERUBAHAN MASYARAKAT}

I Ketut Sunarya

FBS Universitas Negeri Yogyakarta

Abstrak

As human creation, fine art is a human or cultural fact as well as a semiotic fact. A fine art has a specific existence that distinguishes it from other human facts, that is an existence feature inseparable from the balance consideration between reason and feeling. Therefore, despite an artist' freedom in actualizing and appreciating what he wants to express, he needs to hold the basic principle of fine art, namely its closeness to human life. The basic concept of the art is as a starting point and the artist' mirror to reflect his duty to keep its potential of typical areas and to open new art horizon in creating a now lassifiction system. This is a real step expected to deternine the at's posto and bargaining value in this rapid growing era.

Key words: fine art, and social changes

\section{A. Pengantar}

Ada apa dengan kriya? Pertanyaan di atas nampaknya sangat sederhana, namun dari pertanyaan yang sederhana ini merupakan pangkal tolak dalam berpikir untuk pergerakan kriya. Penulis merasa perlu untuk memulai dari konsepsi dasar semacam itu, karena hal ini yang harus dikaji dan dijawab oleh pakar kriya, kriyawan atau pecinta kriya tatkala bergerak bebas dan berekspresi. Jawaban yang sekaligus mampu memberi gambaran atas gonjang-ganjing keraguan sebagian orang yang menyatakan dan meyakini bahwa pergerakan kriya tidak wajar, tidak berlandaskan pada dasar pijak yang pasti, dan dikatakan pergerakan yang cenderung melirik bahkan mengambil kapling daerah lain. Lebih ironis lagi pergerakan kriya dianggap galauan yang bersifat retorika belaka agar seni ini bicarakan orang dan merupakan hal yang tidak wajar.

Benarkah demikian? Jika dikaji lebih jauh fenomena aktivitas ilmiah dalam kriya tanpa disadari telah menjadi bagian sejarah dalam ruang dan waktu yang sangat lama. Bahkan sampai hari ini pun keniscayaan ilmiah dalam pengkajian seni tersebut telah beringsut sangat luas. Bukankah kriya lahir bersamaan dengan manusia ada di jagat raya ini? Kesejarahan ini pun menjadi ciri dari suatu produk kriya seperti kelekatannya dengan kehidupan manusia. Telah diketahui bahwa sejak berabad-abad yang lalu seni ini memiliki fungsi yang transdental dan hadir pada setiap kegiatan manusia. Dengan redaksi keserasian antara nilai estetika, etis dan nilai-nilai keagamaan, dan ini merupakan tanda

Imaji, Vol.4, No.2, Agustus $2006: 187$ - 197 bahwa kriya tidak hanya tunduk pada logika murni seni itu sendiri, tapi memperhatikan logika etis tempat kriya diciptakan.

Telah dikemukakan oleh Gustami (2002: 9), bahwa kriya merupakan cikalbakal atau akar seni rupa Indonesia yang kehadirannya tergayut 3 (tiga) tujuan yaitu pragmatis, magis dan hiburan. Dalam tujuan pragmatis kriya dihadirkan sebagai alat untuk mempertahankan hidup manusia (peralatan), sedangkan tujuan magis agama dan kepercayaan menjadi patron utama. Dalam tujuan hiburan, kriya dihadirkan memberikan kepuasan atau untuk kesenangan di mana kriya tersebut dihadirkan, seperti produk souvenir, cindera mata dan lainnya.

Kenyataan di atas memberi gambaran bahwa seni kriya tidak lepas dari kancah area seni yang menjadi "tanda" atau menyuguhkan sebuah warna zaman. Selain itu, kriya juga merupakan produk yang merefleksikan pola pikir dan prilaku masyarakat pada zamannya, sehingga kriya selalu berkembang sesuai konstelasi zaman. Walaupun terkadang membuat orang tidak mengenali dunia keseharian (ordinary life) dari kriya. Hal itu terjadi karena dalam proses transformasi wujud serba rumit, serawut bahkan tiba-tiba, dan membuat sebagian orang terkejut dan dikatakan bersifat aliennasi (keterasingan dari realita) Akan tetapi, semuanya merupakan sesuatu yang wajar dalam perkembangan seni. Bukankah eksperimen dalam disiplin kriya sama pentingnya dengan proses eksperimen dalam seni lainnya? Meskipun kita menyadari bahwa sebuah eksperimen kadang berhasil dan kadang pula menemui kegagalan, tidak berarti kriyawan harus meniadakannya. Karena eksperimen merupakan salah satu bentuk dialektika dalam mencari identitas, maka dari itu kehadiran kriya tidak cukup hanya menyuguhkan sebuah warna zaman, namun juga merefleksikan pola pikir dan pola perilaku masyarakat serta individu, sehingga dalam setiap kehadirannya mempunyai peran tersendiri.

B. Peran Kriya Dulu dan Kini (Studi Kasus Kriya Yogyakarta)

1. Kriya Yogyakarta Estafet Angkatan 60-an

Strom of druk. Kalimat ini cukup santer terdengar di tahun 1970, pada saat itu perupa ukir kayu di bawah komando Gudaryono menggelar karyanya di Art Gallery Senisono Yogyakarta. Hadirnya pola pembaharuan kriya yang saat itu bernama seni kerajinan dalam bentuk "ukir kayu kreatif" yang sepadan dengan pengertian contemporary craft cukup mengejutkan para pakar seni. Hadirnya karya kriya yang bersifat personal dan mencoba mengimbangi posisi terhormat yang mengelompokkan diri dalam seni murni (fine art) yang dianggap "seni atas". Tampilnya karya Sp. Gustami dengan keunikan dalam bentuk kerumitan yang meliuk-liuk, diimbangi oleh Narno, S. yang unik dalam konsep penyederhanaan bentuk. Sedangkan M. Soehadji mengolah tema kepahlawanan bangsa dan mengajak pikiran penikmat untuk melihat semangat para pejuang di medan

Perkembangan Seni Kriya di Tengah Perubahan Masyarakat (I Ketut Sunarya) 
perang, begitu juga Sukarman, Gudaryono, Sukasno, Sutadi, Sadukut, Saiman, Sutarno, Sudarmono dan lainnya. Di bawah bimbingan Tukiyo HS. HM. Bakir, L Sukani, Fadjar Sidik dan Abas Alibasyah mereka mencoba mendobrak alur dan membuka cakrawala ukir kayu, mengejutkan pakar seni. Ide-ide liar mengalir sedemikian rupa. Tampilan ukir kayu kreatif yang penuh imajinatif mampu menggugah perasaan penikmat. Walaupun saat itu masyarakat melihat sesuatu yang aneh, unik tentang tampilan ukir kayu, namun sangat menarik sehingga mampu menyedot perhatian pengunjung.

Berbagai komentar muncul, termasuk komentar dalam buku tamu dengan mengatakan bahwa gebrakan kriya baru luar biasa dan harus terus berkembang. Suatu komentar yang memberi dorongan kepada kaum kriyawan untuk bergerak maju. Lepas dari berbagai komentar yang ada, memang hasil karya yang dipamerkan tersebut barulah merupakan hasil eksperimen yang masih mencari-cari, namun keberanian mereka dalam membuka jalan memberi angin segar tentang perkembangan kriya ke depan. Pola dasar kriya yang kiranya tidak hanya bertugas merelokasi motif daerah ke daerah lain, namun suatu gerakan yang nantinya menuju kepada pola-pola dan motif-motif yang kreatif, sehingga hasilnya tidak lag menunjukkan kedaerahan lagi. Lahirlah bentuk pola-pola yang individualistik atau menunjukkan gaya kepribadian seseorang. Karya-karya kriya menapak pada gaya kebaruan, motif-motif tradisional yang selalu tampil pada even-even sebelumnya "tersisihkan", dengan motif unik-aneh yang nyeleneh. Jika lembaran baru tersebu di atas kita buka, jadilah era tersebut (tahun 70-an) merupakan suatu pencerahan dan juga pemahaman tentang perkembangan kriya ke depan. Oleh karena itu berpegang pada kesadaran dalam mencari pengakuan, para kriyawan harus melakukan jibaku juang dengan kerja keras yang tidak mengenal putus asa Semangat berkreasi mencari terobosan-terobosan baru yang diharapkan mampu memasuki wilayah fenomena multitafsir kriya itu sendiri.

Tahun 1972 dalam rangka Dies Natalis STSRI "ASRI" XXIV kembali kriyawan unjuk pamer di Gedung STSRI "ASRI" Gampingan Yogyakarta Kehadiran mereka seakan sudah ditunggu-tunggu oleh masyarakat. Hal itu terbukti ketika apa yang mereka tampilkan mendapat sambutan yang cukup meriah, baik dari masyarakat umum mau pun dari para seniman. Wacana ukir kayu kreatif pun mulai merebak, berbagai tanggapan mengenai konsepsi dasar dan bahkan batasanbatasannya, bahkan keraguan dan kebingungan para pakar seni terhadap ukir kayu kreatif (contemporary craft) melahirkan istilah "kriya banci" pada saat itu. Para ahli pun mengatakan bahwa kriya mengalami tingkat produktivitas yang cukup tinggi dan pada umumnya kehadirannya terdapat dua tarikan kuat atas hasil kegelisahan, di satu pihak tetap mempertahankan kriya sebagai applied art dan di lain pihak mengarah ke fine art. Pertanyaan pun muncul berkisar pada keinginan generasi tua untuk mempertahankan kriya pada tataran pemenuh kebutuhan akan fungsi, dan dikatakan sesungguhnya apakah yang tidak bagus pada ukiran kayu tradisional (applied art), sehingga tidak pantas untuk digarap dan dipamerkan.?

Bertolak dari pertanyaan di atas Gustami (1984: 21), mengungkapkan tiga kesadaran yang harus dipegang kaum kriyawan yaitu sadar sebagai pewaris yang bertanggungjawab, sadar akan tuntutan dan tantangan zaman, dan sadar akan perubahan dan perkembangan. Dengan kata lain kehadiran berbagai bentuk kriya berhubungan erat dengan kehidupan manusia itu sendiri. Adanya berbagai kejadian dengan beragam bentuk persoalan memberikan makna tersendiri, dalam bentuk dunia arti dan nilai yang dapat diangkat oleh masing-masing pribadi kriyawan. Di sini terlihat dua dimensi penting dalam pengembangan kriya kayu yaitu pengembangan kemampuan (capabilities) kriyawan itu sendiri dan penggunaan kemampuan agar bisa sepenuhnya terlibat dalam segenap aspek kehidupan serta untuk mengekspresikan diri secara bebas dan kreatif. Dua dimensi yang harus dipandang sebagai satu kesatuan yang utuh terpadu, dan memberikan bobot aktualisasi kriyawan di masyarakat.

Dinamika kemajuan dalam menyetujui semangat kesadaran di atas, adalah cermin strategi pengembangan kriyawan yang mampu berkreasi mencari jati diri. Munculnya kriyawan angkatan 80-an seperti AN. Suyanto, Zaenuri, Andono, Gofar, Tri Purwanto, Supri Aswoto, I Made Marjaya, Muria Zuhdi, Aripta, bahkan sampai pada I Nyoman Dana, I Wayan Suardana, I Ketut Supir, I Nyoman Sila, I Ketut Sunarya, Yulriawan Dafri, Agus Ahmadi, Guntur, Suhartati, I Made Suparta, Joko Suripto, Suharto, Muhajirin dan masih banyak yang lainnya. Walaupun semangat yang mereka tampilkan pada akhirnya hilang dan tenggelam ditelan waktu, namun kemunculan mereka dapat memberikan warna tersendiri dalam kriya saat itu. Selain itu pula peran mereka sebagai pemegang estafet pemicu semangat untuk generasinya tidak dapat dikesampingkan.

Tahun 2000 kriya yang dimotori keluarga besar ISI Yogyakarta kembali meledak di Galeri Nasional Indonesia Jakarta, dengan mengusung tema Kriya Seni, Tahun 2000. Hadirnya generasi penerus seperti Anjar Ragil, I Nyoman Purnama, Basuki, Edi Eskak, Eko Abdul Mufid, Hartadi, Heri Pujiharto, Gede Pasek, I Kadek Arnawa, Indro Baskoro, M. Khoirul Ulum, Pristiyanto, Priyadi Mahmud, I Made Sukanadi, Sumarsono, Udi Yahya, Bagus Indrayana, Noor Sudiati, Titiani Irawani, Djandjang Purwosejati, Heri Pujiharto, dan lainnya Pameran yang mengundang berbagai komentar, seperti diungkapkan oleh Hastanto (2000:2), dikatakan bahwa pameran ini merupakan gerak sosialisasi kriya seni atau kriya kontemporer kepada masyarakat luas, maka dari itu dibutuhkan komitmen bersama untuk saling menerima dan memahami segala

Perkembangan Seni Kriya di Tengah Perubahan Masyarakat (I Ketut Sunarya) 
friksi dan perbedaan yang ada. Bangkitnya kriya kontemporer merupakan kesadaran kaum kriyawan akademik sebagai agen pembaharuan kriya itu sendiri, yang disebut juga dengan agen of change (Bandem, 2000:3). Mengingat, memberi semangat baru dalam kriya merupakan tugas memupus sikap tidak percaya diri atau minderwaardig (Ismail, 2005)

Dalam konteks di atas penulis menyitir proses kreatif dalam teori intertekstualitas, bahwa proses kreatif tidak lahir dari kekosongan, dan bukan membuat suasana dari tidak ada kemudian menjadi ada. Proses kreatif bukan saja dimungkinkan ketika seseorang diandaikan memiliki sesuatu yang ingin direpresentasikannya, tetapi lebih dari itu yaitu kemampuan seseorang dalam cara yang baru, atau kemampuan memodifikasi bahan-bahan yang sudah ada dengan memberi semangat tertentu. Hal ini berkaitan dengan penajaman substansinya, mencari gaya yang lain dari aslinya dengan ciri perbedaan (difference) untuk menuju pada sifat simulacrum (Piliang, 2004:61). Artinya kreatif tidak hanya gerak yang sekedar meniru apa yang telah ada dan ataupun merelokasi gaya yang sudah ada "mapan", tetapi lebih kepada pencarian dan penciptaan entitas-entitas baru.

2. Eksistensi Kriya

Sebagai hasil ciptaan manusia, kriya merupakan fakta kemanusiaan atau fakta kultural di samping sebagai fakta semiotik. Kriya memiliki eksistensi yang khas yang membedakan dari fakta kemanusiaan lainnya. Hal ini juga tidak lepas bahwa seni ini dibangun atas dua aspek yaitu aspek luar dan aspek dalam. Dengan demikian kehadiran kriya memiliki eksistensi ganda, yakni pertama dalam dunia inderawi dan kedua dunia kesadaran yang nonempirik. Aspek keberadaan yang pertama dapat ditangkap oleh indera manusia, artinya karya kriya mempunyai wujud yang terdiri dari cekung-cembung, krawangan, krawingan, garis getakan, tatahan kasar, halus dan lainnya. Semuanya itu merupakan kode-kode tertentu yan dapat difahami bersama. Karena kode adalah setiap "wujud" yang mengandung makna, dan hal inilah terkait dengan aspek nonempirik. Fakta ini pun membuktikan bahwa kriya cenderung mementingkan kualitas estetis, dalam pengertian kualitas keindahan selain juga skill (craftsmanship), dan menjadi variabel penting dalam menetapkan kualitas. Ini menjadi penting dan perlu dipahami dengan seksama melalui suatu kajian yang menyeluruh oleh kaum kriyawan, agar dapat dipakai untuk membangun suatu body of knowledge, dan sebagai upaya pengembangan kreativitas yang mempunyai pijakan kuat.

Geliat ukir kayu kreatif yang telah diuraikan di atas suatu bukti yang mendasar bahwa sebagai pewaris yang bertanggung jawab, kriyawan sadar akan tuntutan, perubahan dan perkembangan zaman. Sebagai produk budaya, kriya sebagai pengganti dari istilah kerajinan berkembang dalam wilayah konsep

Imaji, Vol.4, No.2, Agustus $2006: 187$ - 197 personal cukup pesat, di sisi lain ketergayutan sejarah kriya sebagai pemenuh kehidupan dan aktivitas masyarakat tetap tak tergoyahkan. Kenyataan ini memang mampu menaikkan "makna terhormat" dalam otonomi seni, walaupun belum sepenuhnya dianggap sebagai bagian dari seni yang murni yang memiliki otonomi.

Kriyawan adalah mahkluk individu yang bebas mengaktualisasikan dan mengapresiasikan apa saja yang ia inginkan. Di sisi lain jika ia (kriyawan) menyadari bahwa kriyawan juga mahluk sosial yang semestinya selalu memegang profesi kekriyaannya atau memahami disiplin keilmuannya, maka kontroversial yang menyangkut pengakuan kedudukan otonomi kriya tidak akan terjadi. Seorang kriyawan tidak ubahnya sebagaimana halnya pemain bola "misalnya". Pemain yang bergerak dalam semangat amatirisme profesional tidak bisa dijustisi dengan aturan main di luar batas-batas permainan itu sendiri. Jika ia paham tata aturan dalam permainan tersebut, permainan akan menjad indah, grestek, mengesankan, menarik dan mampu mengajak penonton diam "nyap" pada saat tertentu, serta "bergemuruh" pada saat lain. Masing-masing pemain tentunya mempunyai hak individu dalam bermain cantik dan juga cara tersendiri dalam mengolah bola selama masih dalam lingkup aturan main itu sendiri. Dalam artian bahwa seseorang mempunyai peluang yang selebar-lebarnya untuk terus memainkan perannya, namun konsepsi etis dalam kebebasan mutlak perlu dipahami, setiap olahan masih dalam koridor permainan itu sendiri.

Dari kerangka di atas, kita bisa memahami dan mendefinisikan makna kebebasan dalam penciptaan kriya. Kriyawan memang bebas dalam mengaktualisasikan dan mengapresiasi apa yang diinginkan, namun berpegang pada prinsip kekriyaan merupakan karakter tersendiri. Ini artinya proses kerja yang menghargai fungsi kerja atau karakteristik masing-masing, serta tidak menciptakan fungsi kerja dan atau profesi yang tumpang tindih. Karena fungsi kerja yang tumpang tindih akan mencetak generasi kebingungan profesi, dan berdampak pada kualitas kerja maupun hasil yang diragukan, serta tidak menutup kemungkinan cara-cara seperti ini akan menimbulkan demogagisan dan prahara dalam perkembangan kriya ke depan.

Untuk itu membangun bangun keilmuan kriya sangat penting di era global ini, bergerak dan mencari maknanya sendiri dengan prinsip kecendrungan kemutakhiran sebagai wilayah valid. Mengisi fakta sosial yang bereksistensi imitatif yaitu karya yang merupakan tiruan sesuatu atau bersifat "representasi" (penghadiran kembali). Sifat ini tidak dapat disangkal dalam seni kriya, namun yang lebih penting adalah "representatif rekreatif" yaitu penciptaan yang menonjolkan nilai artistik serta visi kreativitas. Dalam kehadiran tidak hanya menghadirkan sesuatu yang hanya dilihat oleh mata belaka, namun apa yang ditampilkan mempunyai daya cipta yang imajinatif, interpretattif dan evaluatif

Perkembangan Seni Kriya di Tengah Perubahan Masyarakat (I Ketut Sunarya) 
terhadap peristiwa kemanusiaan, sehingga kriya mampu mengungkapkan kesenangan (pleasure) dan pengetahuan (knowledge). Kedua dalam pandangan ekspresif adalah terkait pada curahan jiwa. Kriyawan tidak hanya sekedar mengungkapkan atau memperlakukan sesuatu sebagaimana mereka lihat, tetapi dalam setiap penciptaan karyawan menuangkan lewat emosi dan pengamatan batin. Ketiga dalam pandangan afektif, yaitu karya yang senantiasa berbicara pada orang lain atau karya yang mampu membangkitkan jiwa atau emosi tertentu pada diri penikmat. Karena kriya bukan setumpuk pengalaman seseorang yang diwujudkan dalam bentuk karya, namun juga sesuatu yang mampu membangkitkan pengalaman orang lain.

Semangat kriyawan, jika tidak memperhatikan semangat pembaharuan dan motivasi dinamis akan divonis mandeg dan hanya "imitative". Sebaliknya semangat yang tanpa menghiraukan rambu seni yang semestinya dipahami dan dipegang oleh pencipta seni itu sendiri akan memunculkan karya yang serba mengambang. Oleh sebab itu dalam menggali daerah pijak, kiranya sebuah lirik nyanyian kriya perlu difahami dan dipegang untuk bersama. Suatu koor lirik nyanyian yang mampu memberikan gambaran tentang visi dan misi kriya itu sendiri. Konsepsi mendasar ini mempunyai konskuensi logis yaitu memberikan kekuatan gerak bagi kriyawan sebagai pencipta kriya.

3. Kriya sebagai Catatan Rasa

Konflik dan polemik masalah kriya memang selalu ada dalam setiap komunitas manusia. Karena hakekat kriya tidak lepas dari aktivitas manusia yang hidup dan berinteraksi dengan alam lingkungannya. Manusia yang secara alamiah menjadikan aktivitas hidupnya sebagai objek kesadaran, sehingga dalam proses kriya manusia membangun kodrat dan kapasitas yang ia miliki. Setiap tampilan tidak hanya mimetik dengan maksud utilitarian secara langsung yang harus dibangun, tetapi juga akan memunculkan unsur-unsur tujuan kriya diciptakan. Salah satunya adalah memberikan semangat hidup, karena tidak disadari manusia melakukan sesuatu seperti semua gerak, gores hidup yang telah dilakukan seolaholah ditelan oleh komunitas maupun kebutuhan individual menjadi sebuah pengalaman. Begitu pun manusia dengan alam sekitarnya yang merupakan kesatuan interaksi yang integral. Hubungan yang membentuk karakterisasi manusia itu sendiri, dan menjadi teman dekat untuk diajak berkomunikasi secara seksama. Interaktif yang akhirnya menorehkan dinamika inspirasi manusia melahirkan karya dan menjadi catatan zaman yang dibaca dan menjadi inspirasi bagi setiap generasinya dalam menciptakan catatan baru, seperti apa yang terjadi dalam kriya. Kriya muncul dan menjadi catatan zaman, dan dengan daya pikir manusia yang semakin berkembang, peran kriya sebagai pewarna zaman semakin meluas. Berkembang dengan cara merayap bagai akar tumbuhan yang mencengkeram bumi, dan memunculkan tumbuhan baru yang semakin subur. Kriya sebagai catatan rasa bergerak semakin melebar, mencatat, merambah segala yang ada di bumi. Tidak sekedar meniru apa yang diciptakan oleh Tuhan, namun juga menciptakan entitas-entitas baru untuk memperkaya gayaragamnya yang berlandaskan pada sifat rasio kriya. Sifat yang selalu mempertimbangkan unsur imanen maupun transden, walaupun dalam hal ini belum ada standar ukur yang jelas, namun kehadiran kriya dengan praktek kehidupan kongkrit di masyarakat merupakan fakta yang dapat dipakai sebagai pertimbangan rasio dalam memunculkan "ide regulatif" oleh kriyawan dalam penciptaan kriya lebih lanjut.

Berpijak pada hal di atas, maka, karakter utama karya ini adalah "kegunaan fundamental" yang mengandung agitasi dalam berbagai pertarungan hidup manusia, baik dari panduan "mental template" sampai di era milenium sekarang ini. Oleh sebab itu kriya tidak lepas dari tiga cakupan pokok dalam kebudayaan yaitu wujud gagasan, tingkah laku yang berpola dan hasil tingkah laku. Wujud gagasan merupakan dasar atau ide yang selalu tertuang dalam bentuk konsep setiap penciptaan karya (kriya). Sedangkan tingkah laku yang berpola adalah suatu proses penciptaan yang didasari oleh rencana yang matang, dan hasil karya atau produk. Haryono (2002: 1-2) menegaskan lebih jauh produk yang dihasilkan masa lalu mempunyai klasifikasi menjadi tiga yaitu pertama kelompok teknomic atau artefak yaitu suatu karya yang difungsikan untuk keperluan yang bersifat teknis seperti alat berburu, pertanian, memasak. Kedua kelompok sosio teknis atau sosiofak yang berfungsi sebagai produk penanda atau sebagai setatus sosial seperti perhiasan, busana, hiasan rumah dan ketiga kelompok ideoteknik atau ideofak yaitu karya yang difungsikan untuk keperluan religius atau ritual.

Jika diperhatikan setiap detail dari produk yang dihasilkan dalam konsep yang berujung pada fungsi tersebut di atas, ternyata kualitas ekspresi atau keindahan dari setiap detailnya tidak ditinggalkan. Ini pertanda bahwa pengorganisasian atau struktur kriya ada dua yaitu struktur harmonis dan struktur ritme dengan masing-masing struktur mempunyai fungsi sendiri-sendiri. Struktur harmonis mempunyai fungsi menegaskan dan menggolongkan unsur bahasa estetik, sehingga dari pengamatan lewat struktur ini tercermin keunikan dalam kriya kayu. Sedangkan struktur ritme mempunyai fungsi untuk menentukan unsurunsur yang tertuju pada suatu gerak (ekspresi) yang menjadikan ujud dan terlihat karya dapat dinikmati lewat kasat mata. Lewat kedua struktur ini maka, setiap kelahiran kriya tidak dapat lepas dari wacana di masyarakat. Karena dalam setiap penciptaan, kriyawan akan menjelajahi dunia secara terus menerus, sambil bertanya tentang apa yang telah dilihat. Lewat rasa, mereka asah selanjutnya diolah dan dicurahkan dengan sarana karsa, sehingga menjadi susunan lekaklekuk, krawangan, kruwingan yang rasional sifatnya, tidak lepas dari indah dan

Perkembangan Seni Kriya di Tengah Perubahan Masyarakat (I Ketut Sunarya) 
juga luhur, kudus dan angker tetapi juga grestek dan bizar, serta lucu, menyedihkan, mengejutkan, menggembirakan, dan juga merdu namun dahsyat. C. Membangun Semangat Kaum Kriyawan

Disadari atau tidak, begitu kriyawan berupaya menciptakan karya, di situlah aspek budaya yang terlibat. Budaya bukan perilaku yang kelihatan, tetapi berupa nilai-nilai dan kepercayaan yang digunakan oleh manusia untuk menapsirkan pengalamannya dan menimbulkan perilaku. Budaya juga berupa seperangkat peraturan dan standar dari sebuah perilaku yang layak dan dapat diterima oleh masyarakat. Berpijak pada pengertian ini maka, kriya yang merupakan bagian dari kebudayaan yang kehadirannya tidak dapat lepas dar sifat kelayakan dan diterima masyarakat. Kriya juga dikatakan bagian dari suatu bentuk komunitas umum yang intens. Hal ini bukan saja karena berbagai perwujudannya, tetapi kumunikasi yang disampaikannya berupa pengalaman yang berharga tidak lepas dari imajinasi kreatif sesuai konstalasi zaman. Konsep ini cermin semangat amatirisme kriyawan yang merupakan bagian dari seni, seperti diungkapkan oleh Halim (1988: 6) bahwa seni sebaga ekspresi diri merupakan upaya "keriangan bersama" dan penciptaan solidaritas sosial. Dalam semangat amatirisme tidak ada tendensi komersial, karena kesenian diciptakan atas dasar semangat bersama. Yang menonjol dalam amatirisme adalah solidarias sosial, dimana orang saling berbagi (sharing) berbagai persoalan.

Di era global ini kehidupan manusia semakin maju dan kriya berkembang semakin luas, tidak saja terbatas pada banyaknya hitungan produk, namun juga menjawab bagaimana kedudukannya pada skala-skor-mutu kreativitas. Oleh karena itu kaum kiyawan sudah semestinya tidak melepaskan diri dari tuntutan dan keinginan membentuk (will-to-form), sehingga kriya tidak saja bergulir dalam sesuatu yang linier-monolik melainkan juga algoritmik. Konsep in menjadikan terbendung dalam spirit lokalitas, perspektif instan dan pembaharua yang di dalam setiap pengatur penciptaannya tidak dapat lepas dari fakultas manusia pokok yaitu rasio, perasaan dan sikap religius. Sadali (1983: 8) menyebutkan dengan istilah iman (penghayatan yang dirumuskan dan dilaksanakan dengan perbuatan nyata)

Dalam kriya spirit lokalitas (ritual) misalnya, kaum kriyawan yang bersumber dari kader-kader ulet dan tekun dalam mempertahankan produk adhiluhung, walaupun terselimut oleh gerak putar era, namun mereka selalu siap serta bertanggungjawab sebagai penganut dan pembelaan terhadap produk adat (tradisi) di tanah air. Memang daerah kehidupan kriyawan ini sangat kecil, tetap kemampuan mereka dalam mempertahankan diri pada tekanan-tekanan era memberikan warna khusus setiap karya yang ditampilkan. Salah jika kita mengatakan mereka tanpa ide, karena ungkapan tradisional yang mereka lakukan menyimpan gagasan wujud ideal dari kebudayaan yang sifatnya abstrak. Lokasinya pun ada dalam pikiran warga masyarakat, di mana kebudayaan bersangkutan itu hidup serta memberi jiwa, sehingga gagasan tidak berada lepas dari yang lain, melainkan selalu berkaitan menjadi satu sistem yaitu kehidupan masyarakat yang termasuk di dalamnya hubungan interaksi sosial antara individu didasari pada norma tertentu.

Sedangkan dalam perspektif hipotesis instan tak dihindari hadir produk industri, sebagai awal dari kesadaran manusia akan melakukan agresi terhadap benda di sekelilingnya. Dalam mengisi fungsi ini, struktur intrinsik kriya mengalami perubahan yang mendasar. Kalau sebelumnya merupakan satu kekuatan yang memproduksi, mereproduksi, atau setidaknya merepresentasikan tata kehidupan tradisional, berubah menjadi produk yang hadir untuk menyesuaikan dengan konsumen. Hal ini tidak berarti lumpuhnya semangat amatirisme seiring dengan makin kuatnya budaya komersial. Keseluruhan perubahan ini tampak merupakan manifestasi dari kuantifikasi tata kriya yang berkembang di masyarakat. Di sini kaum kriyawan mencoba mengkaitkan pembelaan atas etika profesi yang selalu berkembang, sehingga tidak begitu ketat melakukan pengawasan pada bidang-bidang kualitatif kekriyaan. Cermin dari kesadaran atas iklim sosial, di mana ekonomi menjadi panglima atau penentu, maka kecendrungan itu menjadi sangat kuat.

Tentunya konsep di atas sangat berlawanan dengan kriya kontemporer yang dimotori oleh kriyawan pembaharuan yang concern terhadap kebebasan dalam menjalankan profesinya. Kriya kontemporer (contemporary craft) merupakan gabungan dari keterampilan, pemikiran desain dan ekspresi seni, maka kehadiran kriya ini tidak menutup kemungkinan akan menjadikan referensi tunggal atas capaiannya. Kriyawan yang bergerak dalam kriya kontemporer tidak memasuki kawasan pengucilan sebagai syarat kreatifitasnya yang terpisah dari keterlibatan dalam realitas keseharian. Karena kriya kontemporer (contemporary craft) didasari oleh semangat menawarkan nilai tertentu yang baru untuk menguji nilai yang sudah ada, semangat amatirisme kriya atas dasar cinta. Dengan ciri tidak saja penuangan ide atau gagasan yang tidak terikat atau "bebas", namun juga jelas dalam menawarkan konvensi nilai-nilai untuk yang sekarang dan akan datang. Sebagai bukti hasil asahan batin kaum kriyawan dalam keresahan cipta, rasa dan karsa serta dalam menangkap tanda-tanda zaman.

Apakah hal ini merupakan gambaran kaum kriyawan yang semakin sumpek oleh bingkai warisan leluhur, yang akhirnya mereka tak perduli akan adanya "wasit kesenian" sebagai penjaga garis depan tradisi? Tentu tidak, mengingat ekplorasi yang dilakukan oleh kaum kriya pembaharuan, merupakan eksitis atau pemikiran atas rasa tanggungjawab generasi di era yang semakin maju,

Perkembangan Seni Kriya di Tengah Perubahan Masyarakat (I Ketut Sunarya) 
generasi yang menawarkan warna baru yaitu kriya kontemporer (contemporary craft) yang berciri individual di era global ini.

\section{Penutup}

Seni identik dengan kebebasan begitu juga kriya, seni yang tidak hanya tunduk pada logika murni seni itu sendiri, namun terkandung juga nilai-nilai logika, etis, dan etika. Untuk itu perkembangan kriya di era sekarang dan akan datang, kriya sudah harus tidak saja suatu produk yang siap menjadi juru bicara sebuah komonitas, namun juga mampu melampui dimensi masa serta tempat untuk dapat didengarkan oleh generasinya. Kenyataan ini sudah pasti merupakan tanggungjawab kaum kriyawan dalam setiap penciptaan karya ada logika dasar. Artinya kaum kriyawan tidak berpegang pada kebebasan mutlak, lugas eksplisit dalam mengungkapkan privasi dirinya yang sangat personal-sentris, namun suatu bentuk kebebasan yang berpegang pada "etika kekriyaan" itu sendiri dalam mencari identitas diri.

Tugas dan tanggungjawab kriyawan dalam tingkah polahnya yang diharapkan mampu meleburkan cipta, rasa dan karsa menjadikan sampurnaning cipta ring idhep untuk membumikan kriya dibuminya sendiri. Agar produk ini kembali menjadi seni yang terbuka, bersetubuh dengan jagat, bersenyawa dengan waktu dan berkembang menjadi catatan rasa di era yang semakin maju, dan tentunya keberadaannya tidak selalu dipertanayakan.

\section{DAFTAR PUSTAKA}

Piliang, Yasraf Amir. 2004. Posrealitas. Yogyakarta: Jalasutra.

Ardika, I Gede. 2000. "Seniman Ditantang Kreatif". Kompas, Sabtu 9 September . Jakarta.

Bangun, C. 2001. Sem, Kritik Seni Rupa. Bandung: ITB.

Bandem, I Made. 2000. Katalog Pameran Kriya Seni. Yogyakarta: ISI Yogyakarta.

Gustami SP 2002. "Memantapkan Wacana Seni Kriya Indonesia Sebagai Akar

Seni Rupa Indonesia” . Makalah Yogyakarta: Program Pascasarjana ISI.

Hastanto, Sri. 2000. Katalog Pameran Kriya Seni. Yogyakarta: ISI Yogyakarta

Haryono, Timbul. 2002. "Terminologi dan Perwujudan Seni Kriya Masa Lalu dan

Masa Kini sebuah Pendekatan Historis-Arkeologi”. Makalah.

Yogyakarta: ISI Yogyakarta.

Ismail, Taufiq. 2005. Pencucian Citra SDM Warisan Kolonial, Peletakan Paradigma SDM Baru, Mungkinkah?. Yogyakarta: UNY.

Halim HD. 1988. "Perlu Dikembangkan Semangat Amatirisme dalam Kesenian". Masa Kini. Yogyakarta. 